Vol. 9 (4): 665-670 (2019)

\title{
ESTIMATION OF SUSPENDED SEDIMENT LOAD BY ARTIFICIAL NEURAL NETWORK
}

\author{
Ş.Y. Kumcu ${ }^{1 *}$, A.E. Tumer ${ }^{2}$ \\ ${ }^{I *}$ Necmettin Erbakan University, Civil Engineering Department, Konya, Turkey; \\ ${ }^{2}$ Necmettin Erbakan University, Computer Engineering Department, Konya, Turkey; \\ *Corresponding author Ş.Y. Kumcu, e-mail: yurdagulkumcu@gmail.com; tumer@konya.edu.tr;
}

Received August 2019; Accepted September 2019; Published October 2019;

DOI: https://doi.org/10.31407/ijees9410

\begin{abstract}
In this study, the monthly flow rate and suspended sediment load $\left(\mathrm{Q}_{\mathrm{s}}\right)$ Karamenderes Stream in Turkey for the years of 1996-2004 were estimated with artificial neural network. Mean square error, mean absolute error and coefficient of determination were used for performance evaluation of the model. The model produced satisfactory results and showed a very good agreement between the predicted and observed data. The results also showed that the performance of the Artificial Neural Network model can capture the exact pattern of the suspended sediment load data in the Karamenderes Stream.
\end{abstract}

Key words: ANN, Suspended sediment load, sediment transport, modeling. 